\title{
Multicultural Integration in Social Studies through Cultural Value of Pancasila Approach: an Effort to Build the Character of Indonesians
}

\author{
Kirana Prama Dewi \\ Primary School Education Department \\ Faculty of Teacher Training and Education \\ Universitas Ahmad Dahlan \\ Yogyakarta, Indonesia \\ kirana.dewi@pgsd.uad.ac.id
}

\begin{abstract}
Indonesia is one of the multicultural countries in the world and is a great nation with its cultural diversity. This diversity is the potential and uniqueness of Indonesian nation. However, the potential and uniqueness are recognized or can cause various problems. Corruption, collusion, nepotism, separatism, robbery, violence, political feud, bullying, poverty, environmental destruction, and the diminution of nationalism and solidarity values are the real problems as well as parts of these diversities. These factors are also the background of the writing of this paper. Multicultural integration in social studies learning needs to be necessarily made as an effort to build the character of Indonesian. Multicultural integration in social studies can be done through inserting multicultural material and made it as a teaching supplementary material. Multicultural integration is carried out through the application of social science concepts based on the diversity utilization that exists in society, especially in students such as ethnic diversity, gender, social status, abilities, language, religion, age, and race. Multicultural integration can be done through cultural values of Pancasila approach. Cultural values of Pancasila approach with the motto "Bhinneka Tunggal Ika" must become the basis of multicultural integration. This approach is regarded as an effort to build the character of Indonesian for the next generation. The character of Indonesian becomes a marker of Indonesia that has a distinct identity with other nations.
\end{abstract}

Keywords- Multicultural in Social Studies; Character of Indonesian; Cultural Values of Pancasila

\section{INTRODUCTION}

Indonesia is a wealthy country. The wealth is not only limited to natural products but also to the various tribes, languages, customs, religions, and beliefs. Indonesia will always be diverse and will continue to be more pluralistic in many ways. This revelation is a truth evidenced by the vast and diverse sociocultural realities and geographic conditions. Currently, the number of islands in Indonesia is as many as 16,056 of large and small islands [1]. The population is over 237 million people, comprises of 633 large ethnic groups or exactly 1,331 ethnic groups according to the population census [2].
Indonesia is a nation with a diversity base on the philosophy of Bhinneka Tunggal Ika. If the diversity of Indonesia is managed well and maximum, it will be powerful and potentially great. On the contrary, if it is not managed properly then it will be a boomerang for Indonesia. Indonesia's diversity is like a double-edged blade. On the one hand, it will be a valuable potential and, on the other hand, it will create conflicts which are capable to destroy the joints of national and state life and even the disintegration of the nation. Bhinneka Tunggal Ika's philosophy which was initiated by the founding fathers of this nation aims to enable Indonesians to coexistence in a safe, peaceful, and prosperous environment.

Furnivall [3] argues that a plural society is a society consisting of two or more elements that live independently without any intermingling with one another in a single political entity. The opinion reinforces the statement that in a pluralistic society there are various groups of people who have different cultural background, religion, customs, and interests. Pluralistic societies usually face the challenge of disharmony and continuous change. Based on the opinion, it appears that the people of Indonesia have such conditions. Vertically and horizontally, Indonesia society is a plural society.

When it is viewed specifically, the pluralism of Indonesia society is seen from the perspective, action, and insight of each individual on various social, cultural, economic, political, and other phenomena. Indonesia society has diverse backgrounds in education, ethnicity, religion, social class, and economy, and has different views and actions on democracy, human rights, gender, and other social phenomena. Some members of society are less supportive of the democratization process, but there are some of them who support the democratization. Some members of the community are very concerned and fight for human rights, and some others are not; some even want to crush the rights of others. There are community members who respond well and support the existence of gender equality, but some others oppose it.

Indonesia is currently facing various problems caused by plurality. The apparent form of such pluralism is political unrest, corruption, collusion, nepotism, poverty, robbery, violence, separatism, environmental destruction, the 
diminishing sense of solidarity and nationalism, and the loss of humanity sense that respect the rights of others. Based on these problems, it is necessary to find a strategy through various fields such as social, educational, cultural, economic, and politic.

As Indonesia grows more culturally diverse, the need for appropriate developmental education which is designed to help the student understand, tolerate, and appreciate cultural differences becomes increasingly critical. Strategy through the field of education can be done as an alternative solution to deal with various problems in Indonesia that are caused by pluralism. Multicultural integration in education is imperative. The concept of multicultural integration in education is focused on understanding and appreciating students' own culture and the cultures of others, including religion, based on the motto Bhinneka Tunggal Ika (Unity in Diversity) and moral values of Pancasila. The implementation strategy of multicultural integration in education can be done by utilizing the plurality that exists in society, especially in students' environment such as ethnic diversity, culture, language, religion, social status, gender, ability, age, and race. This strategy is not only aimed to make students easy to learn the material, but also to raise their awareness to behave humanist, pluralist, and democratic [4].

Multicultural integration can be done by restructuring and strengthen the material charge of Social Studies. This is because social studies learn about human activities, and the best way to learn about human activities is to make sure that every student feels completely as a part of everyday life in the classroom. In other words, the experience is the best teacher. Social study is an effective tool to instil multicultural awareness, because one of the social studies learning missions at the level of primary education is to equip students with a set of knowledge, attitudes, values, moral, and life skills that are useful in understanding someone's self and the environment of the nation and the country [5]. The environment in this context is referred to the ethnic, religion, racial, and linguistic diversity in Indonesia society.

Primary schools play an important role in instilling multicultural values in students. The selection of primary schools in this paper is intended for multicultural integration in social studies through the cultural values of Pancasila approach which embeds on students from an early age. If the primary school students have shared values, tolerance, peace, love, and respect for difference then the value will be attached to their personality. The multicultural integration in social studies through the cultural value of Pancasila approach is a process of fostering a respectful, sincere, and tolerant way of living to the diversity of cultures' live in a plural society. With multicultural integration through Pancasila cultural value approach, it is expected that there will be suppleness and mental flexibility of the next generation in facing social conflict. Students can become the next generation of the multicultural nation who can appreciate differences, uphold the values of democracy, justice, and humanity. Amid the diversity of nations in the world, the next generation of Indonesia must have Indonesian's character. This character becomes a marker of Indonesian identity that is different from other nations.

\section{METHOD}

The method used in this paper was the description analysis of literature study. A literature study was done by finding the relevant theory to the issues discussed. Primary and secondary data were drawn from the various sources used as the main data in this paper.

\section{RESULT AND DISCUSSION}

\section{A. Multicultural Integration in Primary School Teaching and Learning on Social Studies}

The structure of Indonesia society is characterized by its two unique characteristics. Horizontally is marked by the reality of social unity based on differences of ethnicity, religion, customs, regional languages, and regional differences. Vertically is marked by the differences in social status between the top layer and the bottom layer which is quite sharp [3]. Differences in ethnicity, religion, customs, languages, and regional differences are often referred to the characteristic of an Indonesia pluralistic society. Indonesia will always face the challenges of disharmony and continuous changes as the consequences of plural society [6].

The diversity of Indonesia society such as ethnicity, religion, language, customs, and culture can be the basic capital in building the soul of nationalism and patriotism as a great and solid nation. However, this condition is often addressed differently. This pluralism, on the other hand, is considered as a complicating factor and a trigger of conflicts that can harm the Indonesia. Therefore, it needs to be well managed.

The concept of pluralism (multicultural) can be interpreted as a variety of cultures [6]. Ref [7] emphasizes that multicultural is seen from its function as a guide for human life. Furthermore, [7] states that a society should have the concept of multiculturalism in its society. Multiculturalism serves as an ideology that recognizes and glorifies inequality differences, both individually and culturally.

Etymologically, multiculturalism comes from the word multi means plural, the word cultural means culture, and the suffix -ism means flow or trust. Thus, multiculturalism is a pluralistic culture or ideology [6]. Meanwhile, [8] puts forward the notion of multiculturalism relating to three things. First, referring to multiculturalism with respect to culture; second, referring to the diversity that exists; and the third regarding as specific actions on the response to the diversity. So, it can be concluded that multiculturalism is a notion that recognizes the existence of diverse cultures and recognition of the existence of different customs in society. The purpose of multiculturalism is to work together, have equality, and appreciate an increasingly complex life.

Multiculturalism demands society to live a tolerant, an intercultural, and an intercultural understanding in fostering a new world. Regardless of differences of opinion about multiculturalism whether a factor of disintegration or unify of 
the nation of Indonesia, the thing to be noticed is the emergence of ethnic, cultural, and ethnic divisions within the Indonesia. Indonesian is very rich in ethnicity, customs, cultures, languages, and other treasures. Wealth is spread throughout the archipelago and it needs to be kept to avoid trigger disintegration of the nation. This is proved by several events, for example, the tribal conflict between Madurese and Dayak in Sambas (West Kalimantan), conflict on religious issues in Poso (Sulawesi) and Maluku, Aceh separatist movement (Sumatra), or frequent fights between villages in various regions in Java for example in Indramayu District (West Java). Therefore, a sustained effort is needed to increase understanding and awareness of multiculturalism. Such understanding can be done through education.

The formal education way has a very strategic role and function in training, attitude and behavior that reflects multicultural understanding and awareness [9]. Through learning which is developed in schools, every child should adapt and learn to understand that students live in a multicultural environment. Students should be implanted by lateral thinking, diversity, and the uniqueness of a multicultural nation. This means there must be a change in students' attitudes, behaviors, and values. When students come from different backgrounds, students must learn from each other, interact, and communicate, so as to accept the difference between them as something that enriches the brand. Through multicultural integration, it is expected to improve the understanding and training of life skills in a multicultural nation.

Multicultural integration may be related to the curriculum. The developed curriculum should use students' cultural diversity in developing the philosophy, mission, objectives, and curriculum components, as well as the learning environment. It is intended that students can use their personal culture to understand and develop the expected insights, concepts, skills, values, attitudes, and morals.

One of the most meaningful means of multicultural integration is the development of curriculum in the content of social studies learning. Social studies in the primary school play a dual role in promoting diversity and pluralism. First, the classroom climate must be one of respect, dignity, caring, and support for every student. Second, (this role is unique to social studies education), social studies is the study of contributions, traditions, and worldviews of people from all backgrounds, cultures, races/ethnicities, language groups, and religions. In other words, social studies are the study of humankind [10].

Ref [5] states that one of the social studies education missions in primary school is to equip students with a set of knowledge, attitudes, values, morals, and life skills that are useful in understanding the self and the environment of the nation and country. Ref [11] states that multicultural integration in the learning content of social studies can increase awareness, appreciation, and understanding of differences in diverse societies. Thus, multicultural integration in social studies learning content can instill students' attitudes in order to respect others, cultures, religions, and other faiths; moreover, to accept people of different ethnicities, cultures, values, and personalities. The selection of primary schools in the discussion of this paper is that multicultural values can be early instilled through the content of social studies. If the students have an awareness of the values of togetherness, tolerance, love of peace, and respect for the difference from early ages, then those values will form their personality.

\section{B. The Indonesian Character Building Mechanism}

According to the Indonesia big dictionary, the character is defined as a behavior, character, psychological traits, morals or manners that distinguish one person to another [12]. Ref [13] states that character is a guide to all human nature that is fixed, as a special sign to distinguish one person to another person. Ref [14] argues that character is a way of thinking and behaving of a person that characterizes each individual to live and work together, both in family, society, and country. Based on some explanations, it can be concluded that the character is a typical characteristic of a person who is fixed and is distinguished from one person to another person.

The character is a human behavior that deals with God Almighty, self, human, environment, and nationality embodied in thoughts, attitudes, feelings, words, and deeds based on religious norms, laws, manners, culture, and customs. Knowing the existence of a character, one can predict his or her reaction to the phenomenon that arises in him or his relationship with others in various circumstances and how to control it. The character can be found in a person's attitude, towards himself, towards others, of the tasks entrusted to him and in other situations [15].

Ref [16] states that the character can be formed through the stage of formation of thought patterns, attitudes, actions, and habituation. From that opinion, the element of character forming the mind is mind itself. This is because in the mind there are all programs that are formed from the experiences of human life and become the pioneer of everything. The program establishes a belief system and ultimately shapes the mindset. The mindset that is formed will affect human's attitudes and actions. If the program is embedded in accordance with the principles of universal truth, then attitudes and actions will be in harmony with the laws of nature. As a result, these attitudes and actions bring peace and happiness. Conversely, if the program is not in accordance with the principles of universal law, then attitudes and actions will bring harm and produce suffering. Therefore, the mind must get serious attention.

Naturally, from the birth to three years of age, or perhaps up to five years, a child's reasoning ability has not grown yet, so that the subconscious mind is still open and accepts whatever information and stimuli are put into it without any selection. The initial foundation of the character grows up from the parents and the surrounding environment. Furthermore, children's life experiences from the school environment, television, internet, books, magazines, and various other sources increase their knowledge. Such knowledge will lead children to have an increasing ability to be able to analyze and reason outside objects. So, from that event, the role of conscious mind becomes more dominant [15]. 
Furthermore, [15] argue that the more information received and the more mature the belief system and mindset are formed, the more obvious the actions, habits, and unique characters of each individual. In other words, each individual ends up with a belief system, a self-image, and a unique habit. [17] reveal that the basic value to build character is respect. Respect includes respect for oneself, others, and all forms of life and the environment. By having respect, the individual sees him and others as valuable and has equal rights.

Character development to students can be in the form of (1) knowledge; (2) awareness or will; and (3) actions to carry out the character, both to God Almighty, self, environment, and nationality [6]. The building of these characters mandates that with all the diversity of the Indonesia, education in Indonesia is aimed to make the students have the main characters that are humanity human as a person, social man, and human being as a citizen of the nation. Based on these four main characteristics, educational institutions are expected to develop thinking and action habits by focusing on eighteen values of life.

The development of these values is expected to shape the character of the students. Eighteen such characters are religious, honest, tolerant, disciplined, hard work, creative, independent, democratic, curiosity, the spirit of nationality, love of the homeland, respect, friendship, peace of mind, reading, caring, and responsibility. A character-forming value that must be developed is a universal character forming by human beings. Amid the diversity of nations in the world, Indonesia citizen must have Indonesian character. This is a marker of Indonesia that has a different identity with other nations.

The development of the values of the spirit of nationality and love of the homeland is an urgent thing to form Indonesian character. The value of the spirit of nationalism is defined as a way of thinking, acting, and insight that puts the interests of the nation and state above self and group interests. The value of love of the homeland is described as a way of thinking, acting, and doing that shows loyalty, awareness, and high appreciation for the language, physical, social, cultural, economic, and political environment of the nation [6]. Both values are the basis of Indonesian character. The Indonesian character in this context is defined as the Indonesia's human character that distinguishes it from other people. Indonesian character is a manifestation of self-existence and self-image of Indonesia. This notion can be dismissed as a "nationalist character".

Educational activities and processes should be voiced to the nationalist character because the Indonesia has a diversity of religions, tribes, cultures, and customs. The Indonesian character must be developed through the national values that imparted to the learners in the form of national awareness. As a nation that has a long history, the forms of nationalist consciousness's of Indonesia are in the form of pride as a nation, independence and courage as a nation, awareness of honour as a nation, awareness against colonialism, consciousness willing to sacrifice for the nation, nationalism awareness, and regional awareness toward nationalism.

\section{Multicultural Integration in Social Studies through Cultural Values of Pancasila: an Effort to Build Indonesian Character}

The Indonesia adheres to the principle of a pluralistic philosophy, namely Bhinneka Tunggal Ika. This philosophy contains very deep and wide meaning and value for the development of harmony and wholeness of life. Unity in Diversity Bhinneka Ika becomes a unifier of cultural diversity, languages, ethnicities, religions, and customs. The formulation of the idea of Bhinneka Tunggal Ika by founding fathers was attempted so that the journey of this nation can reap the harmony of the differences that exist in the body of the Indonesia.

The approach of Pancasila cultural values in Bhinneka Tunggal Ika principles is very appropriate for social studies. The importance of Pancasila cultural value approach can be seen in three things: first, equality of joints. This equality joint involves the alignment or equal treatment that each student receives regardless of social and economic status; second, a plurality of joints. This joint concerns the condition of Indonesia society which consists of the diversity of tribes, religions, languages, cultures, and customs. So, it is necessary to instill a plurality of understanding to each student that the existence of differences will not hit each other, will not attack one religion to another, and will not undermine a culture to another. Plurality is the breath of Bhinneka Tunggal Ika. The life of a Bhinneka cannot be reflected without any understanding of diversity; third, enforce tolerance. An actualization of the plurality is tolerance. If the understanding of diversity imprints on each individual, it will develop the tolerant attitude in the life of society. As a result, people will live harmoniously in the Bhinneka and build the nation with the Ika.

Multicultural integration in social studies means the learning content in social studies should include material that has a multicultural value. Multicultural values include tolerance, cultural differences, religions, dangers of discrimination, conflict resolution and mediation, human rights, democracy, plurality, and humanity are relevant. Such multicultural values can lead to the formation of a peaceloving civil society and respect for differences. The multicultural material in social studies is provided through the development of a multicultural-based module as social studies supplementary learning content. Modules can be packaged in stories, interesting cases containing messages related to multicultural, thus students can live and feel the implicit meaning from the presented material of social studies.

The National Council for Social Studies (NCSS) [18] proposes a number of functions of multicultural integration in social studies learning, namely (1) give clear self-concept; (2) help to understand ethnic and cultural experiences in history; (3) help to understand that the conflict between ideal and reality exists in every society; (4) help to develop decision making, social participation, and citizenship skills; and (5) recognize the diversity that exists in society.

The learning process is designed so that students can develop mutual respect, tolerance, do not discriminate 
between religions, ethnicities, cultures, and customs. The form of learning model must also contain multicultural values combined with Pancasila cultural value approach. Here are some learning models that can be applied to learning social studies:

1. Cooperative Learning. A learning model that emphasizes team attitudes or behaviors in working in groups. The group consists of two or more persons whose members are not distinguished according to ability. Students are trained to be sensitive to differences and mutual respect for differences.

2. Problem Based Learning. This learning model directs students' early understanding to a higher level. This model requires students to be able to think critically in conducting research to find an alternative solution to a problem.

3. Active Learning. Active learning is any form of learning that allows students to play an active role in the learning process. The interaction between students and students' interaction with the educator are the key to the success of learning.

4. Teaching in Differentiation. A learning model that responds to the needs and abilities of students especially those with special needs. This learning model provides and facilitates the best learning process tailored to the students' conditions and potential.

5. Thematic Integrative. A learning model that develops learning with the theme network. In this lesson, it can relate one lesson to another.

Examples of such learning models enable the development of the character of the students to respect the dignity, freedom of thought, respect for opinions, and respect for differences, collaboration, and critical thinking. Therefore, in social studies learning will be fun, meaningful, and encourage personality optimally.

Multicultural integration in social studies learning through the Pancasila cultural values approach can adopt the following principles:

1. Multicultural integration should start with yourself. This principle emphasizes that multicultural integration must begin with the introduction of oneself. Imprinting that the students are part of the nation's citizens is an important thing to do. Pride as a nation of Indonesia should be a foothold.

2. Multicultural integration should not develop ethnocentrism attitudes. Students' attitudes should be built to raise awareness of life within the scope of nationality. With this attitude, interethnic conflict and hatred can be avoided because of the feeling of one nation. Awareness of one nation even though there are different social groups is an important thing to be developed as a bridge between the soul of nationalism.

3. Multicultural integration can be developed in various aspects. The multicultural curriculum should reach the entire of educational content. Multicultural integration can be carried out in all course contents, such as language, social studies, science, physical education, art, and so on.

4. Multicultural integration must produce change. The change in question is a change of attitude through habituation. Learning practices are designed in a learning environment that value differences, tolerance, cooperation, homeland love, and nationalism. To achieve such atmospheres, learning must be processoriented. For example, active learning, cooperative learning, problem-based learning, role-playing, integrative thematic, and so forth.

5. Multicultural integration must include social reality. Integration must include the social and ethnic reality of religions, ethnicities, cultures, and customs in society. Contextualization must be gradual from local, national, and global level. Pride in the value of local wisdom must be grown. Awareness of nationalism must be a common goal.

Based on the descriptions, multicultural integration in social studies' learning through Pancasila cultural value approach needs to be applied to the formation of mindset, attitude, action, and habituation. Thus, it will foster Indonesian character in students. Indonesian character includes the awareness of pride as a nation, independence, and courage as a nation, the honor as a nation, awareness against the invaders, the consciousness of sacrificing for the sake of the nation, the awareness of nationalism, and the regional awareness toward nationalism. The realization of Indonesian character becomes a strong foundation as characteristic of the Indonesian man who has a motto of Bhinneka Tunggal Ika.

\section{CONCLUSION}

Multicultural integration is a process of building values and ways of living in respecting, sincere, and tolerant of cultural diversity that lives in the mind-set of a plural society. Multicultural integration in social studies' learning means the learning content in social studies should include material that has a multicultural value. Multicultural values include tolerance, cultural differences, religions, dangers of discrimination, conflict resolution and mediation, human rights, democracy, plurality, and humanity which are relevant.

The multicultural material in social studies is provided through the development of a multicultural-based module as a social studies' supplementary learning content. Modules can be packaged in stories, interesting cases containing messages related to multicultural, so students can live and feel the implicit meaning of the material presented in social studies.

The form of learning model must also contain multicultural values combined with Pancasila cultural value approach. Some learning models that can be applied in learning social studies are Cooperative Learning, Problem Based Learning, Active Learning, Teaching in Differentiation, Integrative Thematic and so forth. Examples of such learning models enable the development of the character of the students to respect the dignity, freedom of thought, respect for opinions, and respect for differences, collaboration, and critical thinking. 
Therefore, social studies' learning will be fun, meaningful, and encourage personality optimally.

Multicultural integration in social studies' learning through Pancasila cultural values approach can adopt several principles, such as (1) Multicultural integration should be started from self of individual; (2) Multicultural integration should not develop ethnocentrism attitudes; (3) Multicultural integration can be developed in various aspects; (4) Multicultural integration must produce change; and (5) Multicultural integration must include social reality.

Multicultural integration in social studies' learning through Pancasila cultural value approach needs to be applied to the formation of mindset, attitude, action, and habituation. Thus, it will foster Indonesian character on students. A great nation can only be manifested through a strong human character. Indonesian character will grow by doing multicultural integration in social studies' learning on Primary school level through Pancasila cultural value approach. This is a hope for the great future of Indonesia with the collective belief as a nation that based on the philosophy of Bhinneka Tunggal Ika.

\section{REFERENCES}

[1] Mongabay Indonesia. 2017.

Retrieved from http://www.mongabay.co.id/2017/08/18/dikukuhkan-dinew-york-jumlah-pulau-indonesia-kini-sebanyak/. On 2 Oktober 2017.

[2] BPS. 2013. http://data.go.id/konten/memajukan-kebudayaan-indonesiadengan-satu-data-saatnya-berpartisipasi/. Diunduh tanggal 2 Oktober 2017.

[3] Nasikun, Sistem sosial Indonesia. Yogyakarta: Penerbit Ombak, 2013

[4] H. Farida, \& S. Rahmadonna, "Implementasi model pembelajaran multikultural di sekolah dasar Propinsi Daerah Istimewa Yogyakarta". Jurnal Penelitian Ilmu Pendidikan, vol. 03, Nomor 1, 2010, pp 89-102.
[5] H. Hasan, Pendidikan ilmu-ilmu sosial (buku II). Bandung: Jurusan Sejarah FPIPS IKIP Bandung, 2005.

[6] Y. Suryana, dan H. A. Rusdiana, Pendidikan multikultural suatu upaya penguatan jati diri bangsa: konsep, prinsip, dan implementasi. Bandung: CV Pustaka Setia, 2015.

[7] P. Suparlan, Interaksi antar etnik di beberapa propinsi di Indonesia. Jakarta: Dirjen Depdikbud, 2002.

[8] B. Parekh, Rethinking multiculturalism: cultural diversity and political theory. Great Britain: Mcmillan Press Ltd, 2006.

[9] N. Dantes, Pendidikan teknohumanistik (suatu rangkaian perspektif dan kebijakan pendidikan menghadapi tantangan global). Makalah disampaikan pada Seminar Pendidikan yang Diselenggarakan oleh S2 Pendas PPs Undiksha, 22 Juli 2008.

[10] A. K. Ellis,Teaching and learning primary social studies. Boston: Pearson Education, Inc, 2010.

[11] J. J. Zarillo, Teaching primary social studies: principles and applications. Boston: Pearson Education, Inc, 2012,

[12] I. M. Lapindus, Kamus umum Bahasa Indonesia. Jakarta: Balai Pustaka, 1982.

[13] Zubaedi, Desain pendidikan karakter: Konsepsi dan aplikasinya dalam dunia pendidikan. Jakarta: Kencana, 2012.

[14] IM. Muslich, Pendidikan karakter menjawab tantangan krisis multidimensional. Jakarta: Bumi Aksara, 2011.

[15] A. Majid, \& D. Andayani, Pendidikan karakter perspektif Islam. Bandung: PT Remaja Rosda Karya, 2012.

[16] Wuryanano, Mengapa doa saya selalu dikabulkan. Jakarta: PT Gramedia Pustaka Utama,2011.

[17] Lestari, Sri, Psikologi Keluarga: Penanaman dan Penanganan Konflik alam Keluarga, Jakarta: Kencana Prenada Media Group, 2012.

[18] P. C. Gorski, A brief history of multicultural education. St. Paul, MN: EdChange Multicultural Pavillon, 2001.

[19] S. Lestari, Psikologi keluarga: penanaman nilai dan penanganan konflik dalam keluarga. Jakarta: Kencana, 2013 